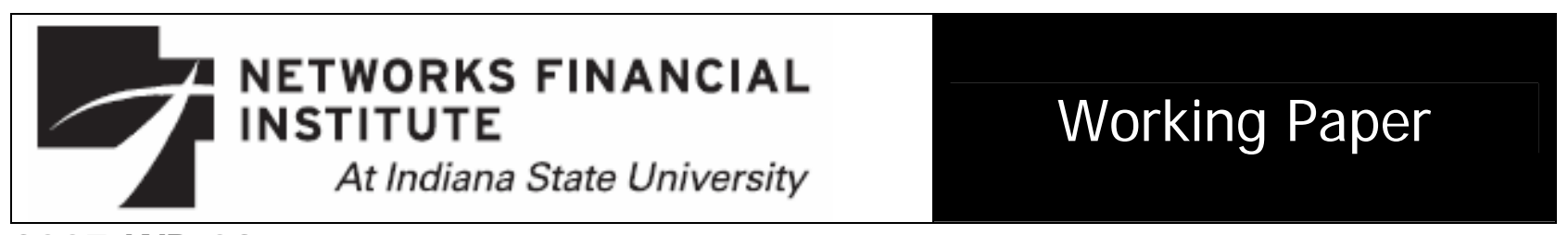

2007-WP-09

February 2007

\title{
Financial Preparation for Retirement: Factors Affecting Retirement Preparation through Employer Sponsored Retirement Plans
}

\section{Kabir Hassan and Dr. Shari Lawrence}

Abstract: This study examines the effect of various social, demographic, and economic variables on retirement preparation and discusses ways in which policy makers can use this information to mandate legislation that will motivate individuals to save for retirement. Using data from the Survey of Consumer Finances, probit analysis indicates that respondents' income and job tenure have significant positive effects on predicting employer sponsored pension plan eligibility. Conversely, the findings do not support the assumption that the probability of pension plan eligibility increases with age and education levels. In addition, we did not find race, marital status or home ownership to be significant factors in pension plan eligibility. Regarding contributions to pension plans, the findings indicate that income, education and net worth have significant positive effects on whether or not an individual is contributing to a plan. Conversely, the findings regarding household size were significant and negative regarding the contribution decision. Race, health, and an individual's savings habits do not appear to have significant effects on the decision to contribute to employer sponsored pension plans. Additional findings; however, indicate that individuals who report the reason for saving is retirement are more likely to contribute to their pension plans. Finally, the results regarding future expectations for the economy were insignificant in relation to whether or not an individual was contributing to his or her pension plan.

The findings may be used to aid policy makers in targeting particular groups of individuals to motivate them to contribute to their company sponsored retirement plans. Policies that encourage retirement planning education programs as well as tax credits on contributions made by individuals in the lower and middle income tax brackets are just a couple of suggestions that could motivate specific groups of individuals to save for retirement.

About the Authors: Dr. Kabir Hassan is a tenured professor at the University of New Orleans and also holds a visiting research professorship at Drexel University, Philadelphia. $\mathrm{He}$ is a financial economist with consulting, research and teaching experiences in development finance, money and capital markets, corporate finance, investments, monetary economics, macroeconomics and international trade and finance. He has published five books, over 70 articles in refereed academic journals and has presented over 100 research papers at professional conferences globally.

Dr. Shari Lawrence is an Assistant Professor of Finance in Nicholls State University. Before coming to Nicholls State University in 2005, Lawrence taught at the University of New Orleans and worked as a financial planner and retirement plan administrator for Asset Planning Services.

Keywords: retirement, financial planning

The views expressed are those of the individual author and do not necessarily reflect official positions of Networks Financial Institute. Please address questions regarding content to M. Kabir Hassan at Kabir_Hassan@comcast.net. Any errors or omissions are the responsibility of the author.

NFI working papers and other publications are available on NFI's website (www. networksfinancialinstitute.org). Click

"Research" and then "Publications/Papers." 


\title{
Financial Preparation for Retirement: Factors Affecting Retirement Preparation through Employer Sponsored Retirement Plans
}

\author{
M. Kabir Hassan and Dr. Shari Lawrence
}

\section{INTRODUCTION}

The current state of retirement preparation among individuals in the United States is woefully inadequate by most standards. Several factors can be attributed to this "perfect storm" of general unpreparedness. One factor is that individual savings rates are at historical lows. Another contributing factor is the demise of traditional employer sponsored retirement plans that guaranteed annuity payments for life. In addition, overall life spans have increased. Why are savings rates so low in this country? One explanation is that price appreciation in the housing market has actually given individuals a disincentive to save. Why bother making the sacrifice to put money away each month when your house is appreciating by $10+$ percent per year. Some individuals may simply be planning on downsizing upon retirement and using the proceeds left over, after purchasing a smaller home, for retirement. The recent cooling of the housing market, however, has put a damper on this strategy.

Another explanation for low savings rates among Americans is that we live in an increasingly consumption oriented society. The savers of the depression era generation have been replaced by younger generations with more materialistic and live-for-the-moment attitudes. This attitude has been fostered by the American culture of wanton materialism.

Besides a low savings rate, the decreased availability of traditional employer sponsored retirement plans is another reason for the current state of retirement plan preparation in the United States. By traditional retirement plans, we are referring to defined benefit plans in which employees generally receive a lifetime annuity based on a percentage of their average salary and years of service in the plan.$^{1}$ Firms have been trying to cut their pension plan costs in order to increase their profitability, or in some cases, reduce their losses. If a firm is currently sponsoring a defined benefit plan, in which employer contributions are required, the easiest way to cut pension costs is to terminate the defined benefit plan and establish a defined contribution plan with discretionary employer contributions. The result is that individuals must increasingly share more of the burden to fund their employer sponsored retirement plans.

It is important to note that you cannot outlive benefits from a defined benefit plan since it is a lifetime annuity. The same cannot be said for defined contribution plans such as $401(\mathrm{k}) \mathrm{s}$, 403(b)s, profit sharing plans, and SIMPLE plans ${ }^{2}$. Under these types of arrangements, an individual's total benefit is his or her account balance. Furthermore, unlike defined benefit

\footnotetext{
${ }^{1}$ Usually, average salaries are based on an employee's last three years on the job. The average may also be based on the three highest earning years, even if these years are not among the last three for an employee.

${ }^{2}$ Note that an individual may purchase a life annuity with his or her defined contribution account balance; however, these are generally fixed payments over a certain number of years. Therefore, it is possible to outlive this type of annuity.
} 
plans, it is the individual who assumes the investment risk in defined contribution plans rather than the employer.

Increased longevity is yet another factor that has put additional strain on the adequacy of retirement preparation. The average 65 year old in 2005 could expect to live until age 86, compared to a 65 year old in 1960 who could expect to live to age $73 .{ }^{3}$ This increase in life span, coupled with low savings rates and fewer pension plans paying lifetime benefits indicates that individuals may indeed outlive their retirement plan dollars if they do not adequately prepare for retirement. This means that goals should be set in order to save enough so that retirement funds can last through one's natural life.

As if the aforementioned issues regarding the lack of retirement preparation were not enough, we also now have to worry about the state of the Social Security System. Recent Social Security reforms, for example, threaten to cut the future benefits of younger workers by indexing those payments to price indexing rather than wage growth as is currently done. Even if workers are allowed to divert a portion of their pay into private accounts, the earnings from private accounts would likely not be enough to make up for the deficit caused by the switch to price indexing. Therefore, as potential sources of retirement funds shift away from employer contributions and Social Security payments, the issue of individual retirement preparation and how to motivate individuals to prepare for retirement has become even more important.

It is imperative for public policy makers to be aware of individual factors affecting participation in employer sponsored retirement plans so that regulations and tax incentives can be instituted to increase participation and contribution rates. Therefore, the purpose of this study is to ascertain the socioeconomic and demographic variables affecting retirement plan preparation. Once these variables have been identified, public policy makers can use this information to mandate legislation favorable to retirement preparation.

The remaining parts of this study are organized as follows: Section 2 provides an overview of retirement savings vehicles. In Section 3, we discuss the issue of low savings rates. In Section 4, we discuss public policy with regard to retirement savings. Section 5 provides a review of previous research on retirement preparation. In Section 6 the data are described. Section 7 describes the empirical model and testable hypotheses. Section 8 discusses the results. Finally, Section 9 provides a summary of the conclusions and discusses policy implications.

\section{RETIREMENT SAVINGS VEHICLES}

At one time, the most common avenue to save for retirement was through employer sponsored retirement plans. These plans are maintained by the business entity and provide income to the employees upon retirement or termination of employment. Employer sponsored retirement plans can be classified as either "qualified" or "non-qualified" depending on the tax status of the plan. The majority of plans are "qualified" so the employer can receive the tax write-off. In order for a plan to achieve "qualified" status, it must meet certain requirements set forth in the Internal Revenue Code. These requirements include a complicated set of rules governing items such as the funding of plan benefits, the level of retirement benefits that can be provided, and which employees must be covered by the plan. Furthermore, a plan must meet certain

\footnotetext{
${ }^{3}$ Sources: Single Life Expectancy Table 1 from IRS Publication 590.

U.S. National Center for Health Statistics, Vital Statistics of the United States.
} 
"nondiscrimination" tests to ensure that the plan does not benefit executives and highly compensated employees more than the rank-and-file employees. As a result of satisfying the aforementioned requirements, qualified plans are entitled to favorable tax treatment. Conversely, "non-qualified" plans do not benefit from favorable tax treatment and therefore do not have to satisfy the numerous restrictions concerning funding, level of benefits, and eligibility for coverage. Hence, "non-qualified” plans can be designed to favor selected employees such as officers or owners. As a result, "non-qualified" plans are said to discriminate in favor of specific employees.

\subsection{Qualified Plans}

There are two types of qualified plans: defined benefit plans and defined contribution plans. During the last few decades, defined contribution plans have experienced increased growth relative to defined benefit plans. According to the International Foundation of Employee Benefit Plans (McCourt, 2006), the number of defined benefit plans in the United States decreased by nearly 70\% from 1980 to 1999 . In contrast, the number of defined contribution plans increased by more that $100 \%$ during the same period. These changes are evident in the aggregate asset amount for defined benefit and defined contribution plans. The amount of assets in defined benefit plans increased from \$0.8 trillion to \$1.6 trillion from 1985-2002 compared to an increase from $\$ 0.4$ trillion to \$1.9 trillion for defined contribution plans during the same period.

One reason for this shift away from defined benefit plans is that it is less costly for firms to maintain defined contribution plans compared to defined benefit plans. With defined benefit plans, firms have fixed cost obligations. However, firms can generally contribute as little or as much as they choose with defined contribution plans. In addition, there is no need to purchase insurance from the Pension Benefit Guarantee Corporation (PBGC). Finally, since defined contribution plans are portable, employees may take their portion of the plan assets when they leave, thus eliminating the firm's cost of lifetime asset management for former employees. This feature is more popular for employees since it enables them to maintain control of their retirement assets throughout their career.

Another reason for the growth of defined contribution plans at the expense of defined benefit plans is changing demographics in the workforce. Defined benefit plans are traditionally associated with the manufacturing industry, labor unions, and large firms; all of which are trending downward. Research indicates that approximately $50 \%$ of the defined benefit to defined contribution shift from 1977-1985 was due to a shift in employment mix. Furthermore, defined contribution plans are replacing defined benefit plans. Hence, the adoption of a defined contribution plan increases the probability that a firm will terminate a defined benefit plan, if it has one in existence.

Defined benefit plans pay a specified amount upon retirement. This amount is calculated using a benefit formula based on the level of income and years of service. Employer contributions made to a defined benefit plan are calculated using actuarial assumptions such as the rate of return, salary increases, and mortality and turnover rates. Plan benefits are partially insured by the PBGC. Since plan participants have been promised a specific amount, investment earnings have no effect on how much the participants will receive upon retirement. Hence, trust 
earnings only affect the amount of the employer contribution. Finally, since the employer's contribution is affected by investment performance, it is the employer who bears the investment risk in defined benefit plans.

Defined contribution plans can be thought of as individual accounts, possibly participant directed, whereby plan assets are allocated to each participant in the plan. Upon retirement, the participant's benefit is simply equal to the individual account balance. Both the employer and the employee can contribute to a defined contribution plan. The amount of the annual contribution is subject to the " 415 limit" under the Internal Revenue Code. Other additions to an individual's account come from forfeitures by those who terminate employment without being fully vested, and from investment earnings ${ }^{4}$. With defined contribution plans, the benefit amount varies depending on the annual contribution and investment performance. Thus, the participant is said to bear the investment risk in a defined contribution plan since the ultimate retirement benefit is affected by investment performance. Finally, assets in defined contribution plans are not insured by the PBGC, and there is no guarantee as to the level of assets upon retirement.

Participants in defined benefit plans become vested in the plan after a certain period of time. Once vested, they may be allowed to obtain loans or hardship withdrawals from the plan. In addition, the participant has the option of receiving a lump sum distribution of his or her vested account balance upon termination of employment.

Defined contribution plans may be more advantageous than defined benefit plans for individuals who plan on changing jobs. The reason is that benefits in a defined benefit plan are generally frozen once the participant terminates employment due to the fact that such benefits are based on the final salary and years of service. However, account balances of participants in defined contribution plans remain invested and therefore are more likely to keep pace with future inflation.

From the firm's perspective, implementing and maintaining a defined contribution plan is more advantageous because contributions are discretionary and the investment risk is passed on to the employees. Alternatively, employees generally prefer defined benefit plans because they do not have to assume any risk and are promised a specified payment upon retirement. However, younger employees may be better off with a defined contribution plan depending on the investment performance of their retirement account.

\subsection{Types of Pension Plans}

\section{Defined Benefit Plans}

Defined benefit plans promise to pay a specific amount to employees when they reach retirement. The amount promised is defined by a benefit formula that is generally related to compensation and service.

\section{Defined Contribution Plans}

Money Purchase Plans-A money purchase plan requires the employer to make an annual contribution whether or not the company makes a profit. The maximum contribution for employees that an employer may deduct is $25 \%$ of all participants' compensation.

Profit Sharing Plans-Employer contributions are not mandatory in a profit sharing plan. The amount the employer contributes to the plan is discretionary. Total contributions cannot exceed $25 \%$ of the sum of all participants' compensation in order to be tax deductible. In addition, the firm need not be profitable in order to contribute to the plan.

\footnotetext{
${ }^{4}$ Source: Internal Revenue Code Section 409A.
} 
401(k) Plans-These plans are popular because they allow both employer contributions and employee deferrals. Therefore, employees are encouraged to participate in saving for their retirement with pre-tax dollars. The maximum deductible contribution for a firm is also $25 \%$ of total compensation with a 401(k) plan.

Stock Bonus Plans-This type of plan is similar to a profit sharing plan except the employer is allowed to contribute to the plan with company stock. Hence, the key advantage is that an employer can make a contribution without a cash outlay.

Simplified Employee Pension Plans-A “SEP” is a plan in which the employer contributes to an IRA for each employee. The advantage of a SEP is the reduction of paperwork involved compared to the standard defined contribution plans.

SIMPLE Plans-A Simplified Incentive Match Plan for Employees allows employees to make a specified contribution based on a percentage of salary. In addition, a SIMPLE plan allows for an employer match.

Koegh Plans-Koegh plans allow self-employed individuals to make tax deductible contributions to a qualified plan.

\section{OUR SAVINGS DILEMMA}

People generally save for many reasons. For example, reasons for saving may include a down payment on a house, a new car, a vacation, or children's education expenses. However, one of the most common reasons for saving is retirement.

As previously mentioned, savings rates in the U.S. are at historical lows. The table below compares net household savings rates among the Organization for Economic Co-operation and Development (OECD) member countries. Note that the United States ranks third from the bottom in 2004 with a meager net savings rate of 1.8\%, followed by Canada at $1.4 \%$ and Australia at -3.0\%. In addition, U.S. savings rates have steadily declined since 1992.

\section{Household Saving Rates as a Percentage of Disposable Income}

\begin{tabular}{|c|c|c|c|c|c|c|c|c|c|c|c|c|c|c|c|}
\hline \multicolumn{16}{|l|}{ Net } \\
\hline Savings & 1990 & 1991 & 1992 & 1993 & 1994 & 1995 & 1996 & 1997 & 1998 & 1999 & 2000 & 2001 & 2002 & 2003 & 2003 \\
\hline Australia & 9.3 & 6.2 & 5.7 & 5.0 & 5.8 & 4.8 & 5.8 & 4.0 & 2.0 & 1.5 & 2.7 & 1.8 & -1.2 & -3.6 & -3.0 \\
\hline Austria & 13.3 & 14.2 & 11.2 & 10.2 & 11.1 & 10.9 & 8.6 & 7.3 & 8.2 & 8.8 & 8.4 & 7.6 & 7.8 & 8.9 & 8.3 \\
\hline Canada & 13.0 & 13.3 & 13.0 & 11.9 & 9.5 & 9.2 & 7.0 & 4.9 & 4.9 & 4.0 & 4.7 & 5.2 & 3.5 & 2.4 & 1.4 \\
\hline Finland & 3.6 & 8.9 & 11.8 & 8.8 & 2.0 & 4.7 & 0.4 & 2.2 & 0.4 & 1.5 & -1.3 & -1.2 & -0.3 & 0.6 & 2.7 \\
\hline France & 9.3 & 10.8 & 11.7 & 12.9 & 11.7 & 12.7 & 11.2 & 12.2 & 11.9 & 11.5 & 11.4 & 12.2 & 13.3 & 12.4 & 11.8 \\
\hline Germany & 13.9 & 12.9 & 12.7 & 12.1 & 11.4 & 11.0 & 10.5 & 10.1 & 10.1 & 9.5 & 9.2 & 9.4 & 9.9 & 10.3 & 10.5 \\
\hline Ireland & 6.1 & 7.2 & 7.2 & 9.7 & 6.0 & 8.5 & 5.8 & 5.9 & 10.8 & 9.8 & 9.2 & 10.1 & 10.5 & 10.7 & 11.5 \\
\hline Italy & 24.0 & 22.9 & 21.4 & 20.8 & 19.2 & 17.9 & 18.9 & 15.4 & 12.2 & 9.8 & 9.2 & 10.1 & 10.5 & 10.7 & 11.5 \\
\hline Japan & 13.9 & 15.0 & 14.2 & 13.7 & 12.6 & 11.9 & 9.8 & 10.0 & 11.0 & 10.7 & 9.5 & 6.6 & 7.2 & 7.4 & 6.9 \\
\hline Korea & 22.5 & 24.6 & 23.4 & 21.8 & 20.7 & 17.5 & 17.5 & 16.1 & 24.9 & 17.5 & 10.7 & 6.4 & 2.2 & 3.9 & 5.1 \\
\hline Netherlands & 13.0 & 9.2 & 11.6 & 8.8 & 9.7 & 9.8 & 8.4 & 8.7 & 8.2 & 4.8 & 1.8 & 4.6 & 5.2 & 5.2 & 7.3 \\
\hline Norway & 2.2 & 2.9 & 5.0 & 6.1 & 5.2 & 4.6 & 2.2 & 2.8 & 5.8 & 5.5 & 5.2 & 4.1 & 8.8 & 9.9 & 10.2 \\
\hline Sweden & 1.2 & 4.0 & 8.6 & 11.0 & 11.3 & 8.7 & 7.5 & 5.4 & 3.3 & 2.3 & 3.3 & 8.5 & 9.2 & 8.7 & 8.6 \\
\hline Switzerland & 9.6 & 10.0 & 10.8 & 11.2 & 11.1 & 11.6 & 11.3 & 10.5 & 10.7 & 10.0 & 11.8 & 11.9 & 9.1 & 8.9 & 8.9 \\
\hline US & 7.0 & 7.3 & 7.7 & 5.8 & 4.8 & 4.6 & 4.0 & 3.6 & 4.3 & 2.4 & 2.3 & 1.8 & 2.4 & 2.1 & 1.8 \\
\hline
\end{tabular}


When personal savings rates decline, individual consumers are not the only ones who are affected. Many economists believe that decreased savings rates may affect the economy as a whole. The reason is that when savings rates decline, there is less money available in the capital markets to be used as loans for firms. This comes full circle for consumers since decreased savings rates may hurt economic growth as a result of fewer dollars available for capital investment. This results in lower economic growth which translates to lower than optimal income growth, less money being contributed toward Social Security, and less money being contributed to pension plans by employers. Thus, inadequate savings rates have a magnified effect on retirement preparation. Individuals may be under the false assumption that if their personal savings rates are low, they still have employer sponsored retirement plans and Social Security to fall back on. While that may be true, consumers do not realize that the three are somewhat interdependent. Hence, lower saving rates may result in less that optimal income from Social Security and employer sponsored pension plans compared to potential levels if personal savings rates were higher.

Another school of thought shared by some economists is that while they acknowledge that personal savings rates are low, this really does not matter because two important features of saving are being overlooked. These are capital gains from investment in real assets and investment assets. The data on personal savings only includes savings from current income. Wealth from capital gains is not included. It has been argued that aggregate savings rates have not really declined because of increases in capital gains, first from the stock market until the dot.com bubble bust, then from the real estate market. While this is certainly possible, it is important to note that unrealized capital gains can easily disappear as we saw when the dot.com bubble burst. A similar situation could occur with the housing market. Therefore, it is more conservative to simply include savings from current income when referring to the household savings rate.

\section{PUBLIC POLICY}

In the past, policy makers have tried several different types of legislation in an attempt to motivate individuals and businesses to contribute more toward retirement savings. Such legislation typically involves an increase in tax incentives or an increase in contribution limits. The result of years of legislation has been mixed. The typical problem is that individuals who are already contributing adequate amounts toward their retirement tend to increase their contributions when favorable legislation is passed. Conversely, individuals at inadequate contribution levels may not be able to afford to take advantage of the new legislation.

\subsection{Past Pension Legislation}

Over the last several decades, Congress has acted several times to enact legislation in order to motivate individuals to save more toward their retirement.

The Technical Amendments Act of 1958-This act allowed taxes to be deferred on both employer and employee retirement plan contributions. However, it was only applicable to employees of religious, charitable, educational, research, and cultural organizations.

The Self-Employed Individuals Tax Retirement Act of 1962-This law, authored by Rep.

Eugene J. Keogh, established Keogh plans. These plans are designed for self-employed individuals, enabling them to make tax-deferred contributions to retirement savings plans. 
The Employee Retirement Income Security Act of 1974 (ERISA)-This act established Individual Retirement Accounts (IRAs) in which individuals became allowed to make tax deferred contributions, subjects to certain restrictions and limitations. In addition, earnings are tax deferred until the time of withdrawal.

The Taxpayer Relief Act of 1997-Authored by Rep. Roth, this act created the Roth IRA. The Roth IRA differs from the traditional IRA established in 1974 in that contributions are made with after tax dollars. However, qualified distributions of contributions and earnings are completely tax free.

The Revenue Act of 1978-This act established 401(k) plans, thereby allowing employers and employees to make pre-tax contributions to these new retirement plans. In addition, earnings are tax deferred until distributions are made.

The Economic Growth and Tax Relief Reconciliation Act of 2001 (EGTRRA)-The passage of EGTRRA was a major step in the government's attempt to motivate individuals to save more toward their retirement. This law increased the maximum annual contribution limits for IRAs as well as 401(k) plans. It also allows individuals age 50 or older to make "catch-up" contributions beyond the maximum annual contribution limits. EGTRRA also allows for certain tax credits. Specifically, employers who establish new retirement plans can receive a tax credit for a portion of the startup costs for the first three years. In order to motivate lower and middle income employees to make contributions to their company sponsored retirement plans, EGTRRA allows for a tax credit of $50 \%$ of annual deferral amounts (up to $\$ 500$ ), subject to certain income limitations.

\subsection{Recent Trends and New Ideas}

We can observe that with the passage of EGTRRA, Congress is trying to address the issue of attempting to motivate lower and middle income employees to save for their retirement. Increasing contribution limits typically benefits individuals in the higher income brackets since they have more discretionary income. In the past, lawmakers have struggled to find ways to target lower and middle income individuals. By allowing tax credits on a portion of employee deferrals for those below specific income thresholds, Congress is clearly trying to reach this target group.

Automatic enrollment in employer sponsored defined contribution plans is another way for policy makers to increase aggregate retirement savings in the U.S. In 1998 and 2000, the IRS issued regulations allowing employers to automatically enroll employees in their retirement plans once eligibility requirements have been met. The theory behind this is that if individuals are enrolled automatically and must complete paperwork to opt out of a plan, overall participation and contribution levels will increase. The advantage of automatic enrollment is that it helps employees at all income levels by automatically enrolling them rather than putting the responsibility on the employee to initiate participation in the firm's retirement plan.

It is a generally accepted view that effective communication and education by the firm regarding the retirement plan features available to employees will have a positive impact on employee participation and contribution levels. In other words, employees are more likely to contribute to their company sponsored retirement plan if they understand the features of the plan. Recent studies by Munnell, Sunden, and Taylor (2000) and Clark and Schieber (1998) have added support to this view. The problem is that it costs firms both time and money to educate their employees as to the characteristics of their retirement plan. The reality is that far too many 
employees do not have sufficient knowledge about their retirement plan in order to make optimal financial decisions. Policy makers can help solve this problem by offering incentives for firms to hold education seminars to inform employees about the characteristics and merits of their respective retirement plans. Congress could enact legislation offering tax incentives in the form of credits to offset the firm's cost to educate employees about its retirement plan.

Several studies have shown that employer matching is positively correlated with employee participation in company sponsored retirement plans [Munnell, Sunden, and Taylor (2000); Clark and Schieber (1998); Xiao (1997); Even and MacPherson (1997)]. Essentially, employees have an extra incentive to participate in a retirement plan if their employer has promised to provide matching contributions. In general, employees will make the financial sacrifice to defer just enough to ensure that they will receive the maximum matching contribution. With this clear relationship between employer matching and employee contribution levels, legislation could be passed to motivate more employers to offer matching contributions. Specifically, employers could be given a tax credit equal to one-half of the employer matching contribution percentage, up to a specified limit. Of course the potential financial benefits must outweigh the costs for this option to be successful.

Finally, distributions from retirement plans are taxed as ordinary income. Conversely, investment returns are taxed as capital gains which are significantly lower than ordinary income tax rates. By passing legislation to tax retirement plan distributions at the lower capital gains rate, this may motivate individuals to begin contributing more toward their retirement.

\section{RECENT LITERATURE ON RETIREMENT PREPARATION}

A few studies have focused on variables that may affect retirement preparation. Specifically, Clark and Scheiber (1998) use personal data records of workers eligible to participate in 401(k) plans. Their study examined the factors associated with variations in both participation rates and employee contribution levels among the eligible employees. Their findings indicate that plan characteristics and communications have the largest impact on employee participation and contribution levels. Hence, this study suggests that employers can improve both plan participation rates and employee contribution levels by implementing a program to better inform employees about the details of the company retirement plan.

Andrews (1992) analyzed participation in 401(k) plans using data from the May 1988 Current Population Survey (CPS). Her findings indicate that plan eligibility increases with age, earnings, family income, and tenure. Regarding contribution levels, Andrews found that older employees have higher contribution rates, as well as those with higher incomes. However, increases in annual earnings did not appear to affect contribution rates. Interestingly, the employer matching feature actually had a negative impact on employee contribution rates. That is, workers tend to contribute less if their plan has a matching feature.

The Employee Benefit Research Institute (EBRI 1994) compared information from the CPS from May 1988 to April 1993. The results indicate that participation rates are slightly higher in 401(k) plans with a matching feature compared to plans without an employer match. Thus, the availability of an employer match has a positive effect on employee participation in an employer sponsored retirement plan.

A more recent study by Xiao (1997) uses tobit regressions to analyze saving motives and 401(k) contribution plans with data from the 1995 Survey of Consumer Finances. The results indicate that possible saving motives for retirement include tax saving, and 401(k) plan features such as 
employer matching, loans, and hardship distributions. In addition, the findings show a positive relation between contributions and risk tolerance, labor income, and years of working. Moreover, Xiao's results regarding risk tolerance support an earlier study by Yuh and DeVaney (1996). Using data from the 1992 Survey of Consumer Finances, the results from Yuh and DeVaney's multivariate analysis indicate that risk averse individuals have smaller amounts of defined contribution funds. In addition, households with lower education levels and less skilled occupations or who were black or hispanic tended to have lower levels in defined contribution funds. Other findings by Yuh and DeVaney indicate that funds increased as years of employment increased.

A related study by Bassett, Fleming, and Rodrigues (1998) found age, income, job tenure and education to be positively correlated with employee participation in a 401(k) retirement plan. Hence, these variables are positively correlated with financial preparation for retirement.

Hayes and Parker (1993) reported that retirement preparation was least pursued by women, single head of households, and the economically disadvantaged. Unfortunately, these groups generally need retirement preparation the most.

In sum, the aforementioned studies have presented some interesting results. The studies have demonstrated that age, income, education, and job tenure consistently have a significant effect on both retirement plan participation and financial preparation for retirement. However, it appears that further research would be beneficial in exploring additional predictors in the area of financial preparation for retirement.

\section{DATA}

The data for this study were obtained from the 1995 Survey of Consumer Finances (SCF) available from the Federal Reserve System in cooperation with the Statistics of Income Division at the Department of Treasury. The SCF is a triennial type of survey and is designed to provide information on households regarding their personal finances, pension plan coverage, labor force participation, and various demographic characteristics. In order to provide accurate information on characteristics that are widely distributed in the population as well as characteristics that are concentrated in a small part of the population, such as home ownership versus investment real estate, a dual frame sample design is used. The purpose is to provide an adequate descriptive base for the analysis of household assets and liabilities. The first part is a geographically based standard multi-stage probability sample whereas the second part is a special over-sample of wealthy families taken from tax records. The second part is necessary because wealthy families hold a disproportionately large share of certain assets, such as tax exempt bonds. The response rate is approximately $70 \%$ for the standard probability sample and about $34 \%$ for the special sample. The survey was conducted by the National Opinion Research Center at the University of Chicago. The Survey consists of 4,299 households, 2,780 from the area probability sample and 1,519 from the list sample. Furthermore, the time frame for the interviews averaged 90 minutes. In addition, there are 4,967 variables and 21,495 observations in the survey. Aside from demographic characteristics, other variables in the survey encompass detailed information on financial assets, nonfinancial assets, and liabilities. Some examples include information on savings bonds, stocks, mutual funds, retirement accounts, life insurance, vehicles, real estate, business assets, and credit card debt. 
In order to accommodate for nonresponse error, statistical methods are used to impute the missing data. Specifically, the missing data in the survey was imputed five times by drawing repeatedly from an estimate of the conditional distribution of the data. These imputations are stored as five successive replicates of each data record. Thus, the number of observations in the data set, 21,495, is five times the actual number of respondents, 4299.

\section{METHODOLOGY}

Respondents aged 65 or less and employed full time were selected for testing from the aforementioned data set. The dependent variables for analysis were grouped into two categories:

1) whether or not the individual is eligible for a retirement plan (ELIG)

2) whether or not the individual is contributing (CONTRIB) to a retirement plan.

The survey respondents self-reported whether or not they were eligible for and/or contributing to a retirement plan and were classified accordingly.

The study uses probit models to address whether retirement savings differs with respect to several socioeconomic factors. ${ }^{5}$ Probit models are appropriate for the purpose of this study since the dependent variables are measures of retirement preparation which suggests the propensity for retirement preparation (Maddala, 1992). ${ }^{6}$

Consider a regression model for retirement plan participation. The respondent is either eligible to be in a retirement plan $(\mathrm{Y}=1)$ or not $(\mathrm{Y}=0)$ for the 1995 SCF survey period. Further, the respondent is either contributing to his retirement plan $(\mathrm{Y}=1)$ or not $(\mathrm{Y}=0)$. The set of independent variables which are gathered in a vector, $\mathrm{X}$, explain the decision, so that

$$
\begin{aligned}
& \operatorname{Prob}(Y=1)=F\left(\beta^{\prime} x\right) \\
& \operatorname{Prob}(Y=0)=1-F\left(\beta^{\prime} x\right)
\end{aligned}
$$

The impacts of the changes in $\mathrm{x}$ on the probability are reflected in the set of parameters $\beta$. For example, the marginal effect of income on the probability of contributing to a pension plan is of interest. However, a model for the right-hand side of the equation must be devised. Thus, a linear regression can be written as

$$
\mathrm{F}(\mathrm{x}, \beta)=\beta^{\prime} \mathrm{x}
$$

Since $E[y]=F(x, \beta)$, the regression model can written as follows

$$
\begin{aligned}
y & =E[y]+(y-E[y]) \\
& =\beta^{\prime} x+\varepsilon .
\end{aligned}
$$

It is hypothesized that several socioeconomic factors are statistically significant regarding eligibility for a retirement plan (ELIG) and whether or not an individual is contributing to a retirement plan (CONTRIB). The specific hypotheses are outlined below:

1) There is a direct relationship between age, education, income, home ownership, job

tenure, net worth and the dependent variable ELIG. Note that eligibility is determined by the regulations of a particular employer's retirement plan. ${ }^{7}$ We expect to see a

\footnotetext{
${ }^{5}$ See Table 1 in the appendix for a complete listing of the socioeconomic factors used as independent variables for this study.
}

\footnotetext{
${ }^{6}$ For a complete description of probit models, refer to Maddala, G.S. (1992). Introduction to Econometrics, 327-330. New York: MacMillan.

${ }^{7}$ The Internal Revenue Code mandates certain minimum requirements for eligibility; however, plan
} 
positive correlation between these variables and pension plan eligibility. Specifically, individuals who are older, better educated, earn higher incomes, have been employed for a significant length of time, and own their own homes are more likely to hold jobs in which they are eligible to participate in an employer sponsored retirement plan. This hypothesis is consistent with previous studies by Basset, W. F., Fleming, M. J. and Rodrigues, A. P. (1998); Malroutu, Y. L. and Xiao, J. J. (1995a); Richardson, V. and Kilty, K. M. (1989); and Kilty, K. M. and Behling, J. H. (1986).

2) Self-employed individuals and non-whites are hypothesized to be less likely to have retirement or pension plans. Previous studies by Xiao, J. J. (1997); Malroutu, Y. L. and Xiao, J. J. (1995a); and Yuh, Y. and DeVaney, S. A. (1996) indicate that nonwhites are less likely to be participants in an employer sponsored retirement plan. This is largely due to self-selection in that there are fewer nonwhites employed in jobs with pension plans compared to whites. Regarding self-employed individuals, a previous study by Crystal and Shea (1990) indicates that the majority of self employed respondents did not have pension plans. Hence, one may conclude that the retirement savings vehicles for the self employed such as Individual Retirement Accounts (IRAs) and Keogh plans are underutilized. Moreover, respondents employed by the government or in the private sector are often encouraged to contribute a portion of their salaries to their employer's retirement plan. Hence, it appears that preretirees in general are not motivated to save for retirement unless they are involved in a mandatory retirement plan.

3) Age, income, education, health, job tenure, RET, NW, PLAN, HAB, INS, RA, and ECON are hypothesized to be directly related to the dependent variable CONTRIB. ${ }^{8}$ In addition to the basic socioeconomic variables commonly used in previous studies, we also look at some different variables such as whether or not the reason for saving is retirement (RET), net worth (NW), the time period for saving (PLAN), saving habits (HAB), whether or not one is covered by private health insurance (INS), risk aversion (RA), and expectations for the economy over the next five years (ECON). We expect to observe a positive correlation between the dependent variable CONTRIB and RET, NW, PLAN, HAB, INS, RA and ECON.

4) There is a direct relationship between household size, OBLIG, RETINC, INH, INC, INT and the dependent variable CONTRIB. ${ }^{9}$ We hypothesize that financial obligations (OBLIG), adequacy of retirement income (RETINC), expectation of inheritance (INH), expectation of future income (INC), and expectations for interest rates (INT) are negatively correlated with the pension plan contributions. Individuals who are anticipating an inheritance, already have adequate retirement savings, or are expecting to have substantial future income will be less motivated to contribute to a retirement plan since they likely do not believe they will need these funds in the future. Furthermore, those with large households or financial obligations are less likely to contribute to a retirement plan because they simply do not have adequate funds to do so. Finally, the expectation of higher interest rates may cause some individuals to worry about the

\footnotetext{
documents generally have age and service requirements such as 21 years old and one year of service to be eligible for participation.

${ }^{8}$ Refer to Table 1 in the appendix for a complete description of these variables.

${ }^{9}$ See Table 1 in the appendix.
} 
economy and consequently their own job security. Thus, they may want to put discretionary funds in a regular savings account rather than a retirement plan in case they need to access these funds for emergency use. ${ }^{10}$

5) Women and unmarrieds are least likely to participate in and contribute to retirement or pension plans. Previous research is virtually unanimous in the conclusion that women are less likely to contribute to a pension plan compared to men. This is largely thought to be the result of more women holding jobs that typically do not provide pension plans.

Another reason is that women typically have more interruptions in their job tenure due to family obligations and therefore may not be eligible to participate in a retirement plan. Regarding marital status, unmarried individuals are, on average, less likely to contribute to a retirement plan compared to their married counterparts due to a less conservative attitude toward future income security.

The following empirical model will be estimated

$$
\begin{aligned}
& y=f\left(x_{1}, \ldots, x_{24}\right)+u \\
& \text { where } \mathrm{y}=\text { eligibility }(0,1) \\
& \text { contributing }(0,1) \\
& \text { and } \quad \mathrm{X}_{1}=\text { age } \\
& \mathrm{X}_{2}=\text { gender } \\
& \mathrm{X}_{3}=\text { race } \\
& \mathrm{X}_{4}=\text { marital status } \\
& \mathrm{X}_{5}=\text { household size } \\
& \mathrm{X}_{6}=\text { income } \\
& \mathrm{X}_{7}=\text { education } \\
& \mathrm{X}_{8}=\text { respondent's health } \\
& \mathrm{X}_{9}=\text { spouse's health } \\
& \mathrm{X}_{10}=\text { household status } \\
& \mathrm{X}_{11}=\text { employment } \\
& \mathrm{X}_{12}=\text { length of employment } \\
& \mathrm{X}_{13}=\text { reason for saving is retirement } \\
& \mathrm{X}_{14}=\text { net worth } \\
& \mathrm{X}_{15}=\text { planning time period for saving } \\
& \mathrm{X}_{16}=\text { saving habit } \\
& \mathrm{X}_{17}=\text { financial obligations } \\
& \mathrm{X}_{18}=\text { private health insurance coverage } \\
& \mathrm{X}_{19}=\text { adequacy of retirement income } \\
& \mathrm{X}_{20}=\text { expectation of inheritance } \\
& \mathrm{X}_{21}=\text { risk aversion } \\
& \mathrm{X}_{22}=\text { expectation of future income } \\
& \mathrm{X}_{23}=\text { expectations for economy } \\
& \mathrm{X}_{24}=\text { expectations for interest rates }
\end{aligned}
$$

\footnotetext{
${ }^{10}$ Note that hardship distributions may be allowed from an employee's defined contribution plan if stated in the plan document; however, hardship distributions are subject to certain restrictions as well as a tax penalty.
} 


\section{RESULTS}

Table 2 presents the descriptive statistics for the dependent variable defined previously as ELIG and all of the various independent variables. Respondents were asked if they were included in any pension plans through work. The results indicate that the average age of respondents is about 45 years. Furthermore, the average length of employment is 12 years. In addition, the majority of respondents were male and the average household size is 3 persons. The condition of respondents' health averaged good to excellent. Finally, the majority of respondents were homeowners and employed by an employer rather than being self employed.

Table 3 presents the probit regression of pension plan inclusion on sociodemographic and economic variables. The findings support the hypothesis that respondents' income, net worth and job tenure are significant predictors of pension plan inclusion. However, the findings regarding employment status yielded mixed results. The assumption that income, job tenure and net worth have positive effects on pension plan inclusion is supported by the findings. These findings are consistent with previous studies by Richardson and Kilty (1989); Malrouto and Xaio (1995a); and Basset, Fleming, and Rodrigues (1998). However, the assumption that education, age, home ownership and being white have positive effects on pension plan inclusion cannot be supported by the results. Indeed, the findings indicate negative marginal effects for education, age and respondents who are white. Finally, for further analysis, we also include the results of the combined effects of the interaction between the age and education variable for particular respondents. The results for this variable were significant and positive. This is consistent with previous studies (DeVaney, 1995). Conversely, significantly negative results were obtained when the age variable was combined with the income and net worth variables. The descriptive statistics for the dependent variable previously defined as CONTRIB, in which respondents are asked if they are currently making contributions to their pension plan, and the independent variables are listed in table 4 . The average age is 45 years and average job tenure is nearly 15 years.

Table 5 lists the results obtained from the probit regression analysis. Contrary to our assumption, as well as previous studies, respondents' job tenure and age were found to have significant negative marginal effects on whether or not a respondent is contributing to his or her pension plan. In addition, the findings indicate that respondents' health, savings habits (HAB), private health insurance coverage (INS) and the time period for saving (PLAN) are not significant as predictors of the contribution variable. However, the findings support our assumption that respondents' net worth and income do indeed have significant positive marginal effects on the decision to contribute. Moreover, the results illustrate significant negative effects regarding household size. The findings show no significance regarding the variables OBLIG (financial obligations), RETINC (adequacy of retirement income), INH (expectation of inheritance), INC (expectation of future income), gender and being married as predictors of contributing to a pension plan.

Some of the findings, however, concur with the results from previous studies. For instance, the findings indicate that education and RET (reason for saving is retirement) both have a significant positive marginal effect on whether or not and individual is contributing to his or her pension plan. These results support earlier findings by Hayes and Parker (1993); Malrouto and Xiao (1995a); and Bassett, Fleming, and Rodrigues (1998). 
Regarding the macroeconomic variables (expectation of future interest rates and expectations for the economy) our results are not significant regarding an individual's decision to contribute to a pension plan. Therefore, contrary to our hypothesis, we must conclude that one's expectations regarding the future of the economy are immaterial when it comes to individual decisions regarding retirement preparation. Finally, our findings regarding risk aversion and the decision to contribute to an employer sponsored pension plan were mixed.

\section{CONCLUSION}

Using survey data from the 1995 SCF, this study analyzes various sociodemographic and economic factors as predictors of employer sponsored pension plan eligibility and contributions. Regarding pension plan eligibility, the findings indicate that respondents' income, job tenure and net worth have significant positive effects on predicting employer sponsored pension plan eligibility. Therefore, individuals who have remained steadily at one job, have higher income and higher overall net worth are more likely to be eligible to participate in a pension plan through work. Conversely, the findings do not support the assumption that the probability of pension plan eligibility increases with age, education and being white. Regarding age, the findings may be due to the fact that the vast majority of pension plans simply have the requirement of one year of service and 21 years of age to become eligible to participate. In addition, the negative marginal effect regarding the education variable may be due to the fact that individuals who do not go on to college enter into the workforce sooner and would therefore become eligible to participate in a pension plan earlier than individuals with more education. Regarding contributions to pension plans, the findings indicate that job tenure and the number of weeks worked per year have significant negative effects on whether or not and individual is contributing to a plan. However, being married, and an individual's race do not appear to have significant effects on contributions to employer sponsored pension plans. Additional findings indicate that individuals with higher income levels, more education and greater net worth are more likely to contribute to their pension plans. Moreover, expectation of inheritance and expectation of future income appear to be irrelevant regarding the contribution decision. The results regarding individuals who stated the reason for saving was for retirement indicate significant positive effects regarding whether on not the individual is contributing to a pension plan. In addition, findings regarding health, saving habits, adequacy of retirement income and the time horizon for saving were insignificant regarding the decision to contribute. Regarding the household size variable, the findings indicate that individuals in large households are less likely to contribute to their respective pension plans.

The results of financial obligations as a predictor of pension plan contributions were mixed. In addition, the results for risk aversion were also mixed. The findings indicate that risk averse individuals are less likely to contribute to their pension plan. More research is needed in the area of risk aversion.

The findings regarding future expectations for the economy were insignificant in relation to whether or not an individual was contributing to his or her pension plan. As with risk aversion, however, further analysis is needed in the area of economic perceptions and how this relates to the motivation to prepare for retirement.

The findings have policy implications for public policy makers. In light of impending reductions in Social Security benefits as well as the decline in traditional defined benefit pension plans, we hope the aforementioned results will aid policy makers in targeting particular groups of 
individuals to motivate them to contribute to their company sponsored retirement plans. Policies that encourage firms to include features in their retirement plans that promote employee contributions should be instituted. Congress has already enacted legislation in recent years to try to promote employee contributions such as automatic enrollment and tax credits for deferrals. However, additional legislation such as tax credits to employers for plan set-up, matching contributions, and employee education would aid in motivating individuals to save for their retirement. More prevalent education programs and matching contributions have the benefits of targeting all employees rather than just those in the higher income brackets. In addition, the government can promote higher contribution rates by increasing the annual contribution limit and providing additional tax incentives. For example, providing tax credits to individuals in the lower and middle income brackets may help to motivate a greater percentage of them to contribute to their respective retirement plans. In addition, since individuals change jobs more frequently today, compared to the past, reducing the time in which new hires become eligible to participate in their company sponsored retirement plan will surely lead to increased national participation rates. Finally, taxing distributions at the lower capital gains rate rather than as ordinary income should also motivate individuals to save for retirement. 


\section{REFERENCES}

Atchley, R. C., (1976). The Sociology of Retirement. Cambridge, MA.: Schenkman Publishing.

Andrews, E. (1992). The Growth and Distribution of 401(k) Plans. In John A. Turner and Daniel J. Beller, eds,. Trends in Pensions, Washington, D.C., USGPO.

Bassett, W. F., Fleming, M. J., \& Rodrigues, A. P. (1998). How Workers use 401(k) Plans: The Participation, Contribution, and Withdrawal Decisions. Federal Reserve Bank of New York, Staff Reports 38.

Beck, S. H. (1984). Retirement Preparation Programs: Differentials in Opportunity and Use. Journal of Gerontology 39 (5), 596-602.

Bixby, L. (1976). Retirement Patterns in the United States, Social Security Bulletin 39, 3-19.

Block, M. R. (1984). Retirement Preparation Needs of Women. Retirement Preparation, Lexington, MA:. Lexington.

Burns, S. A.. (1990). Retirement Savings of Baby Boomers and an Earlier Cohort: 1960 and 1983. The Proceedings of the 36th Annual Conference of the American Annual on Consumer Interests, 322-328. Columbia, MO.

Clark, R. L. \& Scheiber, S. J. (1998). Factors Affecting Participation Rates and Contribution Levels in 401(k) Plans. In Olivia S. Mitchell and Sylvester J Schieber, eds,. Living with Defined Contribution Pensions, University of Pennsylvania Press: Philadelphia.

Crystal, S., \& Shea, D. (1990). Cumulative Advantage, Cumulative Disadvantage, and Inequality among Elderly People. The Gerontologist 30, 437-443.

DeVaney, S. A. (1995). Retirement Preparation of Older and Younger Baby Boomers. Financial Counseling and Planning 6, 25-33.

Employee Benefit Research Institute (1994). Salary Reduction Plans and Individual Saving for Retirement. Issue Brief 155. Washington, D.C.

Engen, E. M., Gale, W. G., \& Scholz, J. K. (1996). The Illusory Effects of Saving Incentives on Saving. Journal of Economic Perspectives 10 (4), 113-138.

Evans, L., Ekerdt, D. J., \& Bosse, R. (1985). Proximity to Retirement and Anticipatory Involvement: Findings from the Normative Aging Study. Journal of Gerontology 40, 368-374. 
Even, W. E., \& MacPherson, D. A. (1997). Factors Influencing Participation and Contribution Levels in 401(k) Plans. Report to U.S. Department of Labor, PWBA.

Fillenbaum, G. G., George, L. K., \& Palmore, E. B. (1985). Determinants and Consequences of Retirement among Men of Different Races and Economic Levels. Journal of Gerontology 40(1), 85-94.

Fitzpatrick, E. W. (1979). Evaluating a New Retirement Planning Program: Results with Hourly Workers. Aging and Work 2, 87-94.

Glamser, F. D., \& DeJong, G. F. (1975). The Efficacy of Preretirement Preparation Programs for Industrial Workers. Journal of Gerontology 30, 595-600.

Green, W. H. (1990). Econometric Analysis, 636-639. New York: MacMillan.

Harris, L., \& Associates. (1975). The Myth and Reality of Aging in America. National Council on Aging, Washington, D.C.

Harris, L., \& Associates. (1981). Aging in the Eighties: America in Transition. National Council on Aging, Washington, D.C.

Hayes, C. L., \& Parker, M. (1993). Overview of the Literature on Pre-Retirement Planning for Women. Journal of Women and Aging 4, 1-18.

Kilty, K. M., \& Behling, J. H. (1986). Retirement Financial Planning Among Professional Workers. The Gerontologist 26, 525-530.

Kim, C. S., \& Wong, K. M. (1997). Asset Allocation Strategies for Personal Pension Contributions. Financial Practice and Education, 35-46.

Kotlikoff, L. J. (1982). The Adequacy of Savings, American Economic Review 72, 1056-1069.

Maddala, G. S. (1992). Introduction to Econometrics, 327-330. New York: MacMillan.

Malroutu, Y. L., \& Xiao, J. J. (1995a). Financial Preparation for Retirement. Consumer Interests Annual 41, 49-54.

Malrouto, Y. L., \& Xiao, J. J. (1995b). Perceived Adequacy of Retirement Income. Financial Counseling and Planning 6, 17-23.

McCourt, S. P. (2006). Defined Benefit and Defined Contribution Plans: A history, Market Overview and Comparative Analysis. Benefits and Compensation Digest 43(2), 1-7.

Monk, A. (1972). A Social Policy Framework for Pre-Retirement Planning. Industrial Gerontology 15, 63-70. 
Montalto, C. P., \& Sung, J. (1996). Multiple Imputations in the 1992 Survey of Consumer Finances. Financial Counseling and Planning 7, 133-146.

Morrow, P. C. (1981). Retirement Planning Programs: Assessing Their Attendance and Efficacy. Aging and Work 4, 244-252.

Munnell, A. H., Sunden, A., \& Taylor, C. (2000). What Determines 401(k) Participation and Contributions. Working Paper. Center for Retirement Research, Boston College, Chestnut Hill, MA.

National Council on Aging. (1980). Retirement Preparation: Growing Corporate Involvement. Aging and Work 3, 1-13.

O’Meara, J. R. (1977). Retirement: Reward or Rejection. The Conference Board, New York.

Poterba, J. M., Venti, S. V., \& Wise, D. A. (1996). How Retirement Saving Programs Increase Saving. Journal of Economic Perspectives 10(4), 91-112.

Purcell, P. (2003). Retirement Savings and Household Wealth in 2000: analysis of Census Bureau Data. Journal of Pension Planning Compliance 29(2), 48-75.

Reich, M. H. (1977). Group Preretirement Education Programs: Whither and Proliferation? Industrial Gerontology 5, 29-43.

Richardson, V., \& Kilty, K. M. (1989). Retirement Financial Planning Among Black Professionals. The Gerontologist 29, 32-37.

Rix, S. E. (1993). Women and Well-Being in Retirement: What Role for Public Policy. Journal of Women and Aging 4, 37-56.

Siegel, S. R., \& Rives, J. M. (1978). Characteristics of Existing and Planned Retirement Programs. Aging and Work 1, 93-99.

Siegel, S. R., \& Rives, J. M. (1980). Preretirement Programs within Service Firms: Existing and Planned Programs. Aging and Work 3, 183-191.

Xiao, J. J. (1997). Saving Motives and 401(k) Contributions. Financial Counseling and Planning Education, 65-73.

Xiao, J. J., \& Malroutu, L. (1994). Saving Motives and Saving Behavior of the Elderly. Consumer Interests Annual 40, 156-163.

Yuh, Y., \& DeVaney, S. A. (1996). Determinants of Couple's Defined Contribution Retirement Funds. Financial Counseling and Planning, 7, 31-38. 
Table 1

\begin{tabular}{|c|c|c|c|c|}
\hline \multicolumn{5}{|c|}{ Table 1} \\
\hline \multicolumn{5}{|c|}{ Description of Independent Variables } \\
\hline Socio-demographic & Human Capital & Work Related & Financial Preparation & Macroeconomic \\
\hline $\begin{array}{l}\text { Under } 30 \\
30-39 \\
40-49 \\
50-59 \\
60-65\end{array}$ & $\begin{array}{c}\text { Income } \\
\text { Amount of income }\end{array}$ & $\begin{array}{l}\text { Employment } \\
\text { Employer } \\
\text { Self employed } \\
\text { Partnership } \\
\text { Other }\end{array}$ & $\begin{array}{l}\text { RET: Reason for saving is retirement } \\
\text { Yes } \\
\text { No }\end{array}$ & $\begin{array}{l}\text { ECON: Expectations over } \\
\text { next } 5 \text { years } \\
\text { Better } \\
\text { Worse } \\
\text { Same }\end{array}$ \\
\hline $\begin{array}{l}\text { Mender } \\
\text { Male } \\
\text { Female }\end{array}$ & $\begin{array}{c}\text { Education } \\
\text { Highest grade completed }\end{array}$ & $\begin{array}{c}\text { Length of } \\
\text { employment } \\
\text { Number of years }\end{array}$ & Amount of net worth & \\
\hline$\frac{\text { Household Size }}{\text { Number of persons }}$ & $\begin{array}{l}\text { Respondent's Health } \\
\text { Excellent } \\
\text { Good } \\
\text { Fair } \\
\text { Poor } \\
\text { NA }\end{array}$ & & $\begin{array}{l}\text { PLAN: Planning the time period for saving } \\
\text { Next few months } \\
\text { Next year } \\
\text { Next few years } \\
\text { Next 5-10 years } \\
\text { Longer than } 10 \text { years }\end{array}$ & $\begin{array}{l}\text { INT: Expectations over } \\
\text { next } 5 \text { years } \\
\text { Higher } \\
\text { Lower } \\
\text { Same }\end{array}$ \\
\hline $\begin{array}{l}\quad \text { Marital Status } \\
\text { Married } \\
\text { Living with partner } \\
\text { Separated } \\
\text { Divorced } \\
\text { Widowed } \\
\text { Never married } \\
\text { NA }\end{array}$ & $\begin{array}{l}\quad \text { Spouse's Health } \\
\text { Excellent } \\
\text { Good } \\
\text { Fair } \\
\text { Poor } \\
\text { NA }\end{array}$ & & $\begin{array}{l}\text { HAB: Saving Habit } \\
\text { Spend more than income } \\
\text { Spending equals income } \\
\text { No plan - save what is left at end of month } \\
\text { Save income of one family member, spend } \\
\text { the rest } \\
\text { Spend regular income, save other income } \\
\text { Save regularly by putting money aside }\end{array}$ & \\
\hline \multirow[t]{6}{*}{$\begin{array}{l}\text { Race } \\
\text { Native } \\
\text { American/Eskimo } \\
\text { Asian/Pacific } \\
\text { Islander } \\
\text { Hispanic } \\
\text { Black } \\
\text { White } \\
\text { Other }\end{array}$} & $\begin{array}{l}\quad \text { Household Status } \\
\text { Homeowner } \\
\text { Renter } \\
\text { Condo } \\
\text { Co-op } \\
\text { Townhouse association } \\
\text { Retirement lifetime } \\
\text { tenancy } \\
\text { Neither rent nor own } \\
\text { NA }\end{array}$ & & $\begin{array}{l}\text { OBLIG: financial obligations } \\
\text { Education of children or others } \\
\text { Healthcare of self/spouse or others } \\
\text { Healthcare/medical expenses } \\
\text { General support in retirement/old age } \\
\text { General support for child/grandchild } \\
\text { General support for parents or others } \\
\text { Home purchase } \\
\text { Purchase of car or other large durable goods } \\
\text { Burial expenses } \\
\text { Taxes } \\
\text { Home repairs/improvements } \\
\text { Weddings/vacation/moving/other } \\
\text { Business/investment } \\
\text { Divorce/legal expenses } \\
\text { Investment/major purchase } \\
\text { Charitable expense } \\
\text { Bills/living expenses } \\
\text { Other } \\
\text { NA }\end{array}$ & \\
\hline & & & $\begin{array}{l}\text { INS: Private Health Insurance Coverage } \\
\text { Yes } \\
\text { No }\end{array}$ & \\
\hline & & & $\begin{array}{l}\text { RETINC: Adequacy of retirement income } \\
\text { Inadequate } \\
\text { Enough to maintain standard of living } \\
\text { Very satisfactory }\end{array}$ & \\
\hline & & & $\begin{array}{l}\text { INH: Expectation of inheritance } \\
\underline{\text { Yes }} \\
\underline{\text { No }}\end{array}$ & \\
\hline & & & $\begin{array}{l}\text { RA: Risk Aversion } \\
\text { Take substantial risk } \\
\text { Take above average risk } \\
\text { Take average risk } \\
\text { Not willing to take any financial risk }\end{array}$ & \\
\hline & & & $\begin{array}{l}\text { INC: Expectation of future income } \\
\text { Increase } \\
\text { Decrease } \\
\text { Same }\end{array}$ & \\
\hline
\end{tabular}


Table 2

Descriptive Statistics of Variables taken from the 1995 Survey of Consumer Finances

Data taken from the 1995 SCF available from the Federal Reserve System in cooperation with the Statistics of Income Division at the

Department of Treasury were used to calculate the mean and standard deviation for the variables listed below.

\begin{tabular}{|l|c|c}
\hline Variable & Mean & Standard Deviation \\
\hline
\end{tabular}

\begin{tabular}{|l|r|r|}
\hline Continuous Variables & & 12 \\
\hline Length of employment & & 11 \\
\hline Age & 45 & 14 \\
\hline Respondent & 32 & 22 \\
\hline Spouse & 3 & 1 \\
\hline Household size & & \\
\hline Income & 88046 & 1243535 \\
\hline Respondent & 12636 & 192820 \\
\hline Spouse & & 3 \\
\hline Education & 14 & 26609338 \\
\hline Respondent & 5299564 & 6 \\
\hline Net worth & 50 & 241 \\
\hline Number of weeks worked per year & 650 & 78183751 \\
\hline Age * Education & 4806590 & 1762045480 \\
\hline Age * Income & 323088515 & \\
\hline Age * Net worth & & \\
\hline
\end{tabular}

$\mathrm{n}=14890$ 


\begin{tabular}{|c|c|c|c|}
\hline \multicolumn{4}{|c|}{ Table 3} \\
\hline \multicolumn{4}{|c|}{$\begin{array}{l}\text { Probit Analysis of Factors Affecting Employee Eligibility in Employer Sponsored Retirement Plans } \\
\text { st squares procedure was employed using data taken from the } 1995 \text { SCF. The coefficient, marginal effect, and P values } \\
\text { dent variables tested in relation to the dependent variable, pension plan inclusion, are tested below. }\end{array}$} \\
\hline \multicolumn{4}{|c|}{ Dependent Variable: Included in pension plans through work } \\
\hline Independent Variables & Coefficient & Marginal Effect & P Value \\
\hline Length of employment & .03441907255 & .01353762955 & .0000 \\
\hline Age of respondent & -.07321536104 & -.02879689548 & .0000 \\
\hline \multicolumn{4}{|l|}{ Race } \\
\hline White & -.1065042625 & -.04189000875 & .0000 \\
\hline Black & .1409834482 & .05545128187 & .0000 \\
\hline \multicolumn{4}{|l|}{ Marital status } \\
\hline Married & -.1075995955 & -.04232082259 & .2312 \\
\hline Living with partner & -.3448520617 & -.1356364106 & .0002 \\
\hline Separated & -.04736163393 & -.01862816768 & .5891 \\
\hline Divorced & .2189649797 & .08612279643 & .0001 \\
\hline Widowed & -.2760967283 & -.1085937229 & .0041 \\
\hline Income of respondent & .000001134895211 & .0000004463743441 & .0000 \\
\hline Respondent's education & -.1837574689 & -.07227506016 & .0000 \\
\hline \multicolumn{4}{|l|}{ Respondent's health } \\
\hline Good & .1713789041 & .06740635185 & .0000 \\
\hline Excellent & .2235458212 & .08792452233 & .0000 \\
\hline \multicolumn{4}{|l|}{ Household status } \\
\hline Rent & -.1481205125 & -.05825841540 & .0140 \\
\hline Own & .1386768621 & .05454406081 & .0163 \\
\hline \multicolumn{4}{|l|}{ Employment status } \\
\hline Employer & -.06870637408 & -.02702343122 & .0981 \\
\hline Self employed & 1.395651406 & .5489343640 & .0000 \\
\hline Retired & .1848831214 & .07271779921 & .0000 \\
\hline Net worth & .00000002182898201 & .00000000858572442 & .0000 \\
\hline Private health insurance & 1.050681971 & .4132517886 & .0000 \\
\hline Government health insurance & -.07025055236 & -.02763078383 & .0397 \\
\hline \multicolumn{4}{|l|}{ Adequacy of retirement income } \\
\hline Very satisfactory & .3921851349 & .1542533449 & .0000 \\
\hline Enough to maintain living standards & .2844382872 & .1118746054 & .0000 \\
\hline Ever received inheritance & -.0009762398534 & -.0003839723880 & .9730 \\
\hline Expectation of inheritance & .1315784046 & .05175211199 & .0000 \\
\hline \multicolumn{4}{|l|}{ Attitudes toward risk } \\
\hline Risk lover & .07617371514 & .02996046843 & .1841 \\
\hline Risk averse & .3242365565 & .1275279681 & .0000 \\
\hline Risk neutral & .2258544904 & .08883256275 & .0000 \\
\hline Expectation of future income & -.03804165195 & -.01496245405 & .1721 \\
\hline Expectation for economy & -.1119745580 & -.04404157266 & .0000 \\
\hline Expectation for interest rates & -.1995928225 & -.07850338461 & .0000 \\
\hline Number of weeks worked per year & .01067396705 & .004198259890 & .0000 \\
\hline Age * Education & .004053590010 & .001594348593 & .0000 \\
\hline Age * Income & -.00000001793914792 & -.00000000705578392 & .0000 \\
\hline Age * Net worth & -.000000000328259578 & -.00000000129110229 & .0000 \\
\hline Log Likelihood = -7583.029 & Predictability $=$ & & \\
\hline
\end{tabular}


Table 4

Descriptive Statistics of Variables taken from the 1995 Survey of Consumer Finances

Data taken from the 1995 SCF available from the Federal Reserve System in cooperation with the Statistics of Income Division at the

Department of Treasury were used to calculate the mean and standard deviation for the variables listed below.

\begin{tabular}{l}
\hline Variable \\
\begin{tabular}{|l|r|r|}
\hline \multicolumn{2}{|c|}{ Mean } & \multicolumn{2}{|c|}{ Standard Deviation } \\
\hline Number of IRA or Keogh accounts owned by respondents & 1 & 1 \\
\hline Length of employment & 15 & 10 \\
\hline Age & & 11 \\
\hline Respondent & 45 & 22 \\
\hline Spouse & 31 & 1 \\
\hline Household size & 3 & 850108 \\
\hline Income & & 460167 \\
\hline Respondent & 106579 & 30577 \\
\hline Spouse & & \\
\hline Education & 14 & 2 \\
\hline Respondent & 3459596 & 19305006 \\
\hline Net worth & 51 & 5 \\
\hline Number of weeks worked per year & 655 & 200 \\
\hline Age * Education & 5840081 & 54236976 \\
\hline Age * Income & 198430134 & 11169712348 \\
\hline Age * Net worth & & 2 \\
\hline
\end{tabular}
\end{tabular}

$\mathrm{N}=2358$ 


\begin{tabular}{|c|}
\hline Table 5 \\
\hline $\begin{array}{l}\text { Probit Analysis of Factors Affecting Employees' Decision to Contribute to Employer Sponsored Retirement Plans } \\
\text { A probit two-stage least squares procedure was employed using data taken from the 1995 SCF. The coefficient, marginal effect, and P values } \\
\text { of each of the independent variables tested in relation to the dependent variable, the employee contribution decision, are tested below. }\end{array}$ \\
\hline Dependent Variable: Is employee currently contributing to plan? \\
\hline
\end{tabular}

\begin{tabular}{|c|c|c|c|}
\hline Independent Variables & Coefficient & Marginal Effect & P Value \\
\hline Length of employment & -.009110389977 & -.003567229038 & .0128 \\
\hline Age of respondent & -.01401262955 & -.005486730992 & .1779 \\
\hline Gender & -.04779033963 & -.01871260041 & .6563 \\
\hline \multicolumn{4}{|l|}{ Race } \\
\hline White & -.1783694714 & -.6984165983 & .0002 \\
\hline Black & .1530459688 & .05992608719 & .0040 \\
\hline Married & .1779136164 & .06966316703 & .4772 \\
\hline Household size & -.008849677508 & -.003465145472 & .7629 \\
\hline Income of respondent & .00001079911819 & .000004228460921 & .0000 \\
\hline Respondent's education & .03233393347 & .01266054984 & .3338 \\
\hline \multicolumn{4}{|l|}{ Respondent's health } \\
\hline Good & .4023359284 & .1575370989 & .0004 \\
\hline Excellent & .4384800059 & .1716895340 & .0002 \\
\hline Reason for saving is retirement & .01367368125 & .005354013705 & .0000 \\
\hline Net worth & .00000000747235161 & .0000000029258450 & .5878 \\
\hline Ten year time horizon for saving & -.1146416381 & -.04488863609 & .1878 \\
\hline Five year time horizon for saving & .1157787109 & .04533386390 & .0811 \\
\hline \multicolumn{4}{|l|}{ Saving Habit } \\
\hline Spending exceeds income & 1.132859670 & .4435781478 & .0005 \\
\hline Spending equals income & .4079590962 & .1597388847 & .1223 \\
\hline No plan, save what is left & .5953373275 & .2331079797 & .0134 \\
\hline Save from one family member & .7490798330 & .2933068001 & .0031 \\
\hline Spend regular income, save other & 1.095094303 & .4287908867 & .0000 \\
\hline Save regularly & .2941774313 & .1151869764 & .2291 \\
\hline \multicolumn{4}{|l|}{ Financial obligations } \\
\hline Home purchase & .08971851600 & .03512983487 & .3184 \\
\hline Healthcare & -.1384568017 & -.05421360938 & .3983 \\
\hline Children's education & .03429771846 & .01342948189 & .6652 \\
\hline Private health insurance & .5094149060 & .1994645289 & .0009 \\
\hline Government health insurance & -.4097368482 & -.1604349744 & .0000 \\
\hline \multicolumn{4}{|l|}{ Adequacy of retirement income } \\
\hline Very satisfactory & .3923832668 & .1536400732 & .0002 \\
\hline Enough to maintain living standards & .1144221747 & .04480270384 & .0716 \\
\hline Ever received inheritance & .1576248306 & .06171896859 & .0290 \\
\hline Expectation of inheritance & .1094811109 & .04286800002 & .1561 \\
\hline Risk lover & .1260027726 & .04933715793 & .4565 \\
\hline Risk averse & -.07615917612 & -.02982059223 & .4076 \\
\hline Risk neutral & .1929617351 & .07555535015 & .0085 \\
\hline Expectation of future income & -.08215144588 & -.03216690218 & .2443 \\
\hline Expectation for economy & -.08601688791 & -.03368043970 & .1875 \\
\hline Expectation for interest rates & -.05033427968 & -.01970869573 & .4007 \\
\hline Number of weeks worked per year & -.04965431273 & -.01944245050 & .0000 \\
\hline Age * Education & .0007198093120 & .0002818457482 & .3526 \\
\hline Age * Income & -.0000002272882682 & -.000000088996114 & .0000 \\
\hline Age * Net worth & -.0000000001179552 & -.000000000046186 & .6022 \\
\hline
\end{tabular}

Log Likelihood $=-1418.821 \quad$ Chi-squared $=429.0416 \quad$ Predictability $=.65$ 